\title{
P-7 CHARACTERISTICS OF AL QARQAF ARCH, THE GHADAMIS AND MURZUQ BASINS, W LIBYA - AN INTEGRATION OF RS, SEISMIC AND AEROMAGNETIC DATA
}

Y.A. AL FASATWI', P.M. VAN DIJK' ${ }^{1}$ and A.A. MISSILATI ${ }^{2}$ International Institute For Aerospace and Earth Sciences, PO Box 6, 7500 AA Enschede, The Netherlands 'Biruni Remote Sensing Centre

\begin{abstract}
The mapping of the arch structures of Libya, which separate most Libyan sedimentary basins from each other, can significantly enhance the understanding and modeling of their tectonic formation and deformation history. These arches were effective in localizing truncation, unconformities and onlap of depositional sequences. In addition, they are likely to be focal points for oil migration and accumulation.
\end{abstract}

Al Qarqaf Arch is a major ENE-WSW structural feature in Libya developed during the Hercynian rogeny and separating two large Paleozoic basins, the Ghadamis Basin in the north and the Murzuq Basin to the south (Figure 1). The Arch represents the best exposed and highest basement surface in the area and includes the northernmost exposure of Pre-Cambrian of the. African Craton. The fact thickness of the sedimentary cover on the axis of the arch is less than that in all other arches of Libya may be due to epeirogenic uprising and subsequent erosion which may have acted for a long time after the late Paleozoic.

The research deals mainly with the western Paleozoic basins of Libya. The area of interest lies between the plain of the Nefussah Uplift to the north, the Timboqah Arch to the west, the Murzuq Sand Sea to the south and the Hun Graben to the east. The geographical boundaries are defined between the following coordinates: $24^{\circ} 00$ and $31^{\circ} 00 \mathrm{~N}$ latitude and $10^{\circ} 00$ and $15^{\circ} 00 \mathrm{E}$ longitude.

In this study the sparse but exact dataset of drilling is complemented by the continuous but qualitative interpretation of aeromagnetics, while at the same time the subsurface information of aeromagnetics and well data is complemented by the observation of surface anomalies by remote sensing

The depth of the basement in the Murzuq Basin increases towards the south with a regular gradient. Another observation that can be made from the analysis is that small troughs trending N-S occur in the northern part of the Murzuq Basin. The width of these troughs is in the range of $9 \mathrm{~km}$. They are important for hydrocarbon generation and migration systems where they are suitable areas for deposition of sufficient thickness of source and reservoir rocks.

A regional aeromagnetic map covering the area was analyzed for mapping of basement structures and depths in the area. Several observations can be made when interpreting the aeromagnetic maps and basement structure contour map. Basement features in the area of study are clearly expressed in the magnetic data. The primary expression is as alternating highs and lows. The regional aeromagnetic map shows that those magnetic trends are predominately SW-NE, roughly parallel with the trend of Al Qarqaf Arch. However, another NW-SE trending magnetic high occupies the center of the Ghadamis Basin. This is a regional anomaly parallel to the Tripoli-Tibisti Arch. Modeled basement topography constructed from 
. Wy

aeromagnetic data shows that the topography of the basement in the Ghadamis Basin is roughly subdivided into two parts (east and west) by $\mathrm{NW}$-SE trending ridgethoth parts of the Ghadamis basin show irregular topography with deeper basement on the western side. Correlation of basement topography in the Ghadamis and Murzuq Basins indicates that the basement topography in the Murziiq Basin is smoother than in the Ghadamis Basin.

The surface lineaments on the Landsat TM, Spot XS and Radar ERS-1 images of the area were tested for expression of subsurface (Figure 2). For this purpose the surface lineaments were integrated with the aeromagnetic and seismic data. The combined study reveals that the data sets confirm and supplement each other in identifying subsurface basement structures. Several basement features in the area are clearly expressed in the aeromagnetic data. These features give a clear outline of the Ghadamis and Murzuq Basins and Al Qarqaf Arch. Furthermore; a relationship appears to exist between the major basin forming structures defined during the present study and the location of the known hydracarbon discoveries, especially in the southern parts of the Ghadamis Basin.

The following conclusions can be made from the analysis:

1. The integration of multiple data sets of Al Qarqaf Arch, the Ghadamis and Murzuq Basins including remote sensing images, seismic data, aeromagnetic data and well data has given a better understanding of the tectonic process, surface and subsurface structural styles resulting from the various deformational phases.

2. The aeromagnetic anomalies show N-S trending highs and lows extending across Al Qarqaf Arch and northern parts of the Murzuq Basin, these highs and lows are most probably representing basement horst and grabens structures.

3. There is good correlation in trends and in some cases both trend and location between basement structures mapped in aeromagetic maps and surface lineaments mapped in remote sensing images. These positive correlations especially in the flanks of the Ghadamis and Murzuq Basins strongly suggest that the sedimentary section has been influenced by the underlying basement architecture.

4. The relationship between regionally prominent lineaments and hydrocarbon exploration is of primary importance. It appears that reactivated basement faults in the area of study influenced both sedimentation, structures and as well as hydrocarbon migration and accumulations.

5. There is a good correlation in the flanks of the two the basins between the location of major basement structures, trends and surface structures mapped in remote sensing images. These positive correlations strongly suggest that underlying basement structures have influenced sedimentary section. 


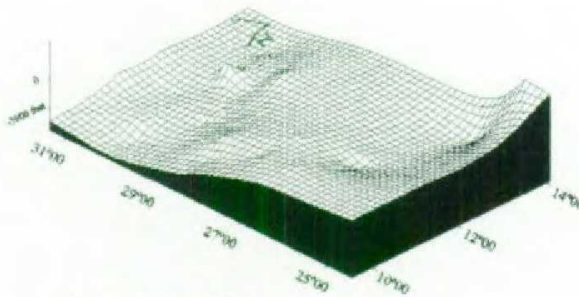

E. Early Devonian,

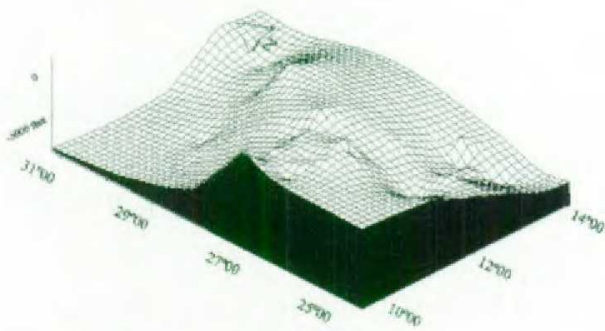

C. Early Silurian.

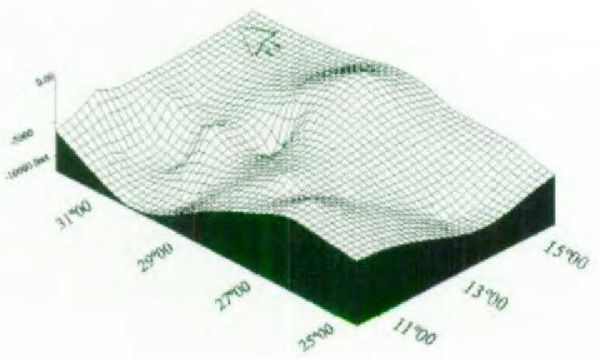

A. Late Cambrian-Early Ordovician.

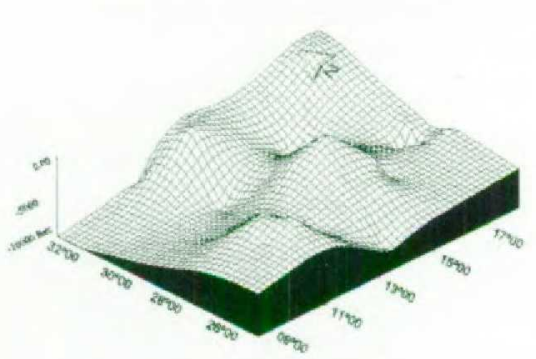

Basement topography

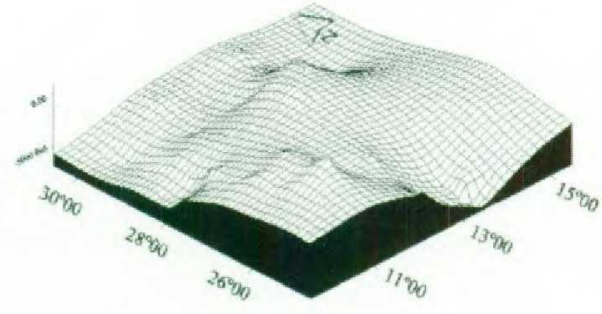

G. Late Devonian

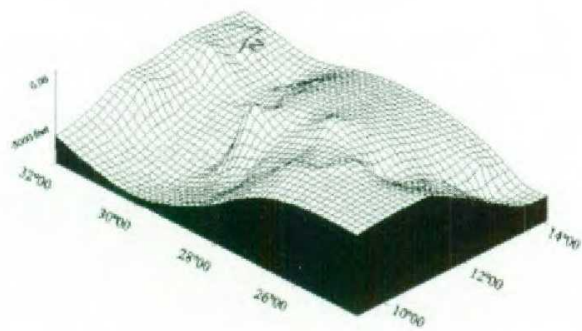

D. Late Silurian.

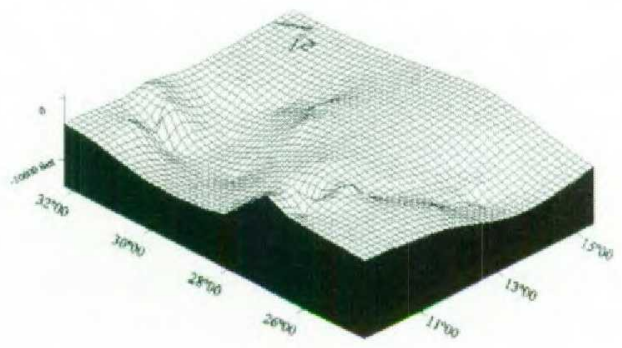

B. Late Ordovician.

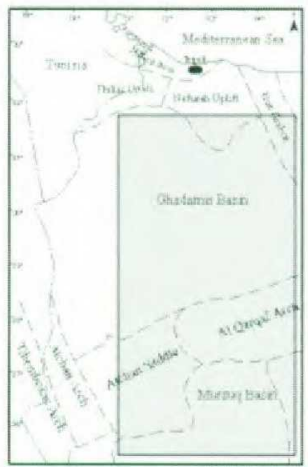

Figure 1. Modeled topography of Al Oarqaf Arch. The Ghadamis and Murzuc Basins resulted with interpolation with kriging of well data. 


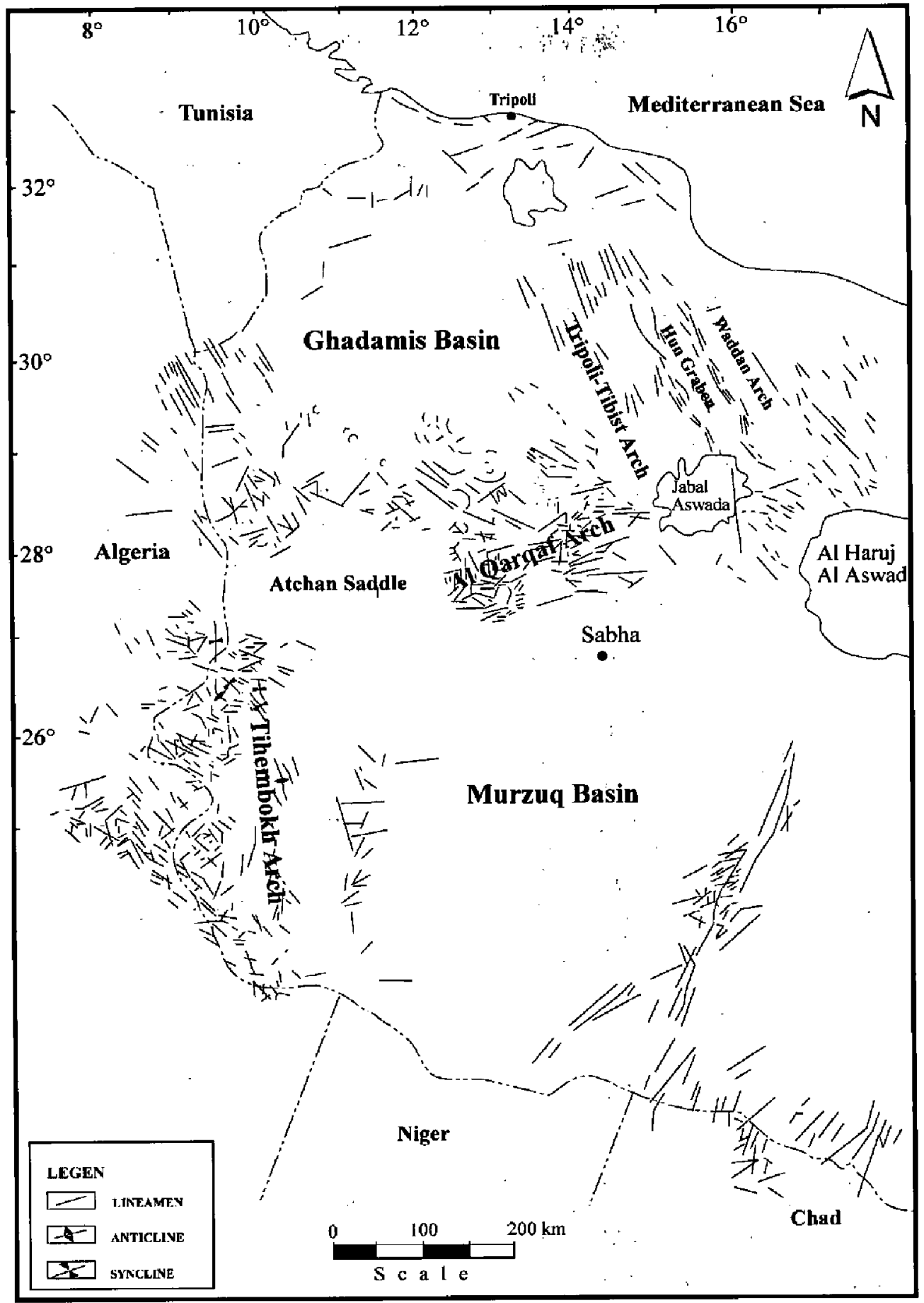

Figure 2. Lineaments interpreted from satellite images of the study area. 